\title{
Fish pass assessment in the rivers of Catalonia (NE Iberian Peninsula). A case study of weirs associated with hydropower plants and gauging stations
}

\author{
Marc Ordeix ${ }^{1}$, Quim Pou-Rovira ${ }^{1}$, Núria Sellarès ${ }^{1}$, Mònica Bardina ${ }^{2}$, Anna Casamitjana ${ }^{2}$, \\ Carolina Solà ${ }^{2}$ and Antoni Munné
}

${ }^{1}$ Centre d'Estudis dels Rius Mediterranis-Museu Industrial del Ter. Passeig del Ter, 2. 08560 Manlleu, Catalunya.

2 Agència Catalana de l'Aigua, Departament de Medi, Territori i Sostenibilitat de la Generalitat de Catalunya. Carrer de Provença, 204-208. 08036 Barcelona, Catalunya (anmunne@ gencat.cat).

* Corresponding author: cerm@mitmanlleu.org

Received: 24/3/2010

Accepted: 1/4/2011

\begin{abstract}
Fish pass assessment in the rivers of Catalonia (NE Iberian Peninsula). A case study of weirs associated with hydropower plants and gauging stations

This study evaluated the effectiveness of fish passes in Catalan rivers (NE Iberian Peninsula). The aim was to test current functionality to enhance these structures for the purpose of optimising their management. We analysed river connectivity and fish pass facilities to generate information to improve the design, construction, management and assessment of solutions related to fish passage in Catalan rivers according to international best practices. In 2006, a preliminary evaluation of the locations and effectiveness of fish pass facilities in Catalonia was conducted through direct inspection of 78 fishways. Most of them were retro-fitted solutions using broad-spectrum technical structures, mainly pool fishway or pool pass facilities. An analysis of the effectiveness of 7 of the new fish passes (4,2 and 1 passes in the Ter, Ebro and Tordera rivers, respectively) was performed between 2006 and 2009. The fish passes were located in weirs associated with hydropower plants and gauging stations. Our preliminary assessment of fish connectivity was based on a field visit and collection of information to populate a database of existing obstacles and associated fishways and calculation of the new version of the ICF index (river connectivity index) for all of them. Several methodologies were used to check the effectiveness of a selection of fish pass solutions, most of which were based on passage rates directly or indirectly estimated for each species. Direct estimation techniques involved the installation of fish traps upstream of the facility at the exit of the fish pass and visual counts. Indirect estimation techniques compared the fish population structure on each side of the obstacle in river sections with equivalent hydrology and habitat characteristics using electric fishing or trapping systems, group mark-recapture methods and individual mark-recapture methods (PIT tags). The results showed that (1) existing solutions to improve fish migration in Catalonia are insufficient (only present at approximately $8 \%$ of obstacles), and where they do exist, the fish passes are usually inadequate or poorly maintained. (2) Fish passes are generally inadequate or insufficient for the total native fish fauna from each water body. Additionally, with few exceptions, fish passage rates are too low, and in most cases, only fish with a high capacity to overcome obstacles or the largest individuals succeed in migrating. (3) Fish pass effectiveness agrees with the results of the new version of the ICF index.
\end{abstract}

Key words: Fish migration, fishways, river connectivity, hydromorphological assessment, ICF index.

\section{RESUMEN}

Evaluación de dispositivos de paso para peces en los ríos de Catalunya (NE de la Península Ibérica). Estudio del caso de azudes asociados con plantas hidroeléctricas y estaciones de aforo

Este estudio evalua la eficacia de dispositivos o soluciones de paso para peces en los ríos de Catalunya (NE de la Península Ibérica). Se realizó con el propósito de comprobar su funcionalidad actual y también para poder mejorar elementos constructivos y/o para optimizar aspectos de gestión. El objetivo del estudio era analizar la conectividad de los ecosistemas fluviales y generar información para mejorar el diseño, construcción, gestión y evaluación de soluciones para el paso de peces 
en los ríos de Catalunya, de acuerdo con los estándares internacionales. El año 2006 se realizó un estudio de localización y evaluación preliminar de la eficacia de los dispositivos de paso para peces existentes en Catalunya mediante la inspección directa de 78 dispositivos. La mayoría eran soluciones de rehabilitación por medio de estructuras técnicas de amplio espectro, como dispositivos de paso de estanques sucesivos. Entre 2006 y 2009 se efectuó un análisis de la eficacia de 7 de estos elementos (4, 2 y 1 en los ríos Ter, Ebro y Tordera, respectivamente). Los dispositivos de paso para peces estaban localizados en azudes para uso hidroeléctrico y estaciones de aforo. La evaluación preliminar de la connectividad para los peces se basó en una visita de campo y la recolección de información para completar una base de datos sobre los obstáculos existentes y las soluciones de paso para peces associadas. Para cada uno de estos casos analizados se calculó la nueva versión del Índice de Conectividad Fluvial (ICF). Posteriormente, se usaron varias metodologías para comprobar la eficacia de una selección de soluciones de paso para peces, la mayoría basadas en la estimación de la tasa de franqueo de cada especie. Las técnicas de estimación directa consistieron en la instalación de trampas aguas arriba del obstáculo, a la salida del dispositivo de paso para peces, y los recuentos visuales. La estimación indirecta permitió la comparación de las estructuras poblacionales por especie de ambos lados del obstáculo en tramos fluviales de características hidrológicas y de hábitat equivalentes, a partir de muestreos con pesca eléctrica o trampeo, métodos de marcaje y recaptura de grupo, y métodos de marcaje y recaptura individualizados (con marcas PIT). Los resultados obtenidos indicaron (1) Las soluciones existentes en Catalunya para mejorar las migraciones de los peces resultan insuficientes (están presentes sólo alrededor del $8 \%$ de los obstáculos). Cuando los hay, en general, los dispositivos de paso son inadecuados o con un mal mantenimiento. (2) Los dispositivos de paso para peces son generalmente inadecuados o insuficientes para el conjunto de las especies autóctonas de fauna piscícola de cada masa de agua. Las tasas de franqueo de los dispositivos de paso para peces son, con algunas excepciones, demasiado bajas y, en la majoría de los casos, sólo facilitan las migraciones de los peces con gran capacidad de superar obstáculos o los individuos de mayor talla. (3) La eficacia de los dispositivos de paso para peces coincide con los resultados de la nueva versión del índice $I C F$.

Palabras clave: Migración de peces, dispositivos de paso para peces, conectividad fluvial, evaluación hidromorfológica, indice ICF.

\section{INTRODUCTION}

Major obstacles that act as complete barriers to upstream fish passage, such as large dams and weirs, isolate and modify previously contiguous fish communities, which results in drastic changes in the faunal community structure of river ecosystems (Thorncraft \& Harris, 2000). In the case of fish that undergo significant migrations during their life cycle, particularly anadromous and catadromous species, the presence of obstacles prevents their free movement in rivers, which might cause local extinctions above barriers and can greatly reduce population abundance downstream of those barriers.

Longitudinal river connectivity is a basic requirement for fish community persistence, as it allows seasonal movements (migrations), enhances lifetime reproductive success, compensates for drift, allows recolonisation of areas affected by disturbance (e.g., after flooding;
Jungwirth et al., 1998; Thorncraft \& Harris, 2000; Bruslé \& Quignard, 2001; Lucas \& Baras, 2001) and contributes to the conservation of native species (Cowx \& Welcomme, 1998; Elvira et al., 1998a; Aparicio et al., 2000; Granado, 2000; Encina et al., 2001; Porcher \& Travade, 2002; Casals, 2005). Poor longitudinal connectivity in inland waters affecting both upstream and downstream migrations is associated with many inriver structures, from large dams and weirs, to channels for irrigation or hydroelectric plants, turbines and pumping stations, gauging stations, and other factors, such as hydrological and water quality constraints. Moreover, conservation of fish diversity and restoration of river longitudinal connectivity are critical requirements for global biodiversity conservation in Europe (Zitek et al., 2008), meeting the conditions of the Water Framework Directive (WFD; EC, 2000) and for the European Recovery Plan for the Eel (Regulation 1100/2007; EC, 2007). River longitudinal 
connectivity is also extremely important for maintaining the conservation status of many freshwater species included in the Nature 2000 network (Habitats Directive 92/43/CEE; EC, 1992).

According to international standards (Larinier et al., 1994; Thorncraft \& Harris, 2000; Larinier, 2001; Marmulla \& Welcomme, 2002; Armstrong et al., 2004; Kroes et al., 2006), solutions for the improvement of river longitudinal connectivity may be classified into 3 major types: (1) restoration, which implies a total return to an original pristine state by removing obstacles partially or completely; (2) rehabilitation, which involves taking actions to restore connectivity to a previous condition, but without overall full habitat restoration, including fish passes ranging from close-to-natural systems, such as fish ramps, bottom or rock ramps and by-pass channels or streams, to formal constructed systems, such as fish lifts and eel ladders and systems to protect against the entrainment of fish into channels; and (3) management, which entails a set of actions performed at particular times such as the functioning of sluices and ship locks or the implementation of environmental flow regimes.

Fish passage solutions should be prioritised in terms of effectiveness for all groups of native fish fauna potentially present in each river section. This should include groups of species with different swimming or jumping abilities as well as those that are not associated with any commercial or sporting interest or special conservation value. Moreover, fish passage effectiveness is highly dependent on the ease of maintenance and management, which should be considered in the early stage of the design process, as indicated by numerous authors (Jungwirth et al., 1998; Marmulla \& Welcomme, 2002; Armstrong et al., 2004; Garcia et al., 2005; Santo, 2005; Kroes et al., 2006). Thus, the installation of a fish passage device alone is not a guarantee of recovering longitudinal connectivity for fish fauna, unless some basic considerations are ensured:

1. Upstream movements: migrating fish must find the fish pass entry easily and without delays. A critical point here is the location of the fish passes entrance and the attraction flow for fish in relation to the overall flow at the base of the weir or dam. Excessive turbulence within the fish pass device must also be restricted to an appropriate level associated with the tolerance of the species that will use the pass.

2. Downstream movements: when fishes migrate downstream, they must be guided away from potentially damaging components of obstacles (e.g., turbines, pumps, racks) to the bypass or fishway exit. Behavioural and/or physical barriers (e.g., screens, lights, sounds) may be appropriate to guide fish to an alternative route for migration downstream.

3. Maintenance: the fishway should work effectively without frequent maintenance.

Assessment of the effectiveness of fish passage devices can be accomplished by gathering information on obstacle and fishway characteristics so that the degree of impediment for fish passage can be evaluated. Additionally, this information can be used to calculate a river connectivity index, such as the ICF (river connectivity index; Solà et al., 2011). However, fish passage efficiency can also be estimated from fish species crossing rates, which are calculated using a wide array of methods ranging from the installation of fish traps at the upstream exit of the fish pass to the comparison of fish populations at both sides of the obstacle, group mark-recapture methods (upstream and downstream fish populations), individual mark-recapture methods (e.g., with PIT tags), automatic fish counters, visual counts, telemetry or hydroacoustic approaches (Lucas \& Baras, 2001; Travade \& Larinier, 2002; Marmulla \& Welcomme, 2002; Roni, 2005; Santos et al., 2006). These techniques might be more precise than methods based on fishway characteristics. However, they consume a great deal of human and economic resources and, consequently, can only be applied to small geographical areas. Moreover, techniques used to estimate fish crossing rates are subject to the availability of prior knowledge regarding the phenology of fish species, as their movements tend to be concentrated at certain times of the year (RodriguezRuiz \& Granado-Lorencio, 2006) but may vary in 
response to a number of factors (Lucas \& Baras, 2001), such as flow increases (Welcomme, 1980; Jonsson, 1991; Roni, 2005).

More than 1,000 obstacles, above all weirs and dams, have been recorded in Catalan rivers (located in the northeast of the Iberian Peninsula with a surface area of $32,000 \mathrm{~km}^{2}$ ), with only 78 being associated with fish passes (Ordeix et al., 2006). Despite the number of these obstacles, few studies have dealt with fish longitudinal connectivity in Catalan rivers (Elvira et al., 1998a; Elvira et al., 1998b), and they are usually restricted to very specific areas (Catalan et al., 1997; Ordeix et al., 2009a). The presence of these obstacles has seriously affected migratory fish species in Catalan rivers, including the European eel (Anguilla anguilla), which has progressively disappeared from the upstream areas of most dams. Shad (Alosa fallax), sturgeon (Acipenser sturio), which are now locally extinct, and sea lamprey (Petromizon marinus) populations have been similarly affected (Sostoa, 1990; Aparicio et al., 2000; Doadrio, 2001; Sostoa et al., 2003), while other non-diadromous fish, some of which are endemic to the Iberian Peninsula, have also had their migration routes negatively impacted and are consequently now endangered.

The WFD requires achievement of good ecological status by 2015 for all riverine water bodies, which can only be accomplished when fish communities are close to natural conditions and, thus, when river longitudinal connectivity improves, as water pollution and eutrophication processes are already decreasing in Catalonian rivers (ACA, 2009). In addition, the previously implemented Spanish Inland Fisheries Act (1942) has recently been updated in Catalonia (Llei 22/2009, del 23 de desembre, d'ordenació sostenible de la pesca en aigües continentals), supporting the construction of new fishways to improve fish community integrity. To achieve these environmental objectives, it is important to count with standardised assessment tools that can be applied to extensive geographical areas while producing a reliable estimation of fish pass efficiency to improve the design, construction, management and restoration of solutions for fish passages.
In this regard, the objectives of this study are (1) to characterise and evaluate fish passes in Catalan rivers using rapid assessment techniques based on the old and new versions of the river connectivity index (ICF; Solà et al., 2011) and (2) to compare the assessment of fish pass effectiveness derived from quick assessment techniques provided by the ICF index to the estimation of fish pass efficiency from methods that estimate fish crossing rates and compare upstream and downstream fish populations.

\section{METHODS}

This study was conducted in two phases: (1) during 2006, 78 existing fish passes (Ordeix et al., 2006; Fig. 1) were characterised and evaluated in the rivers of Catalonia with the new and old versions of the river connectivity index (ICF; Solà et al., 2011) and (2) during the period from 2006 to 2009 , in situ assessment of the effectiveness of 7 representative fish passes was performed using methods (e.g., fish crossing rates) to estimate the barrier effects on native fish populations upstream and downstream of the obstacles (Ordeix et al., 2009b). Selection of these seven fish passes (Fig. 1) was performed with the aim of integrating different types of river stretches, fish species and fish passes.

\section{Data collection using rapid assessment techniques}

Preliminary assessment of fish longitudinal connectivity in Catalan rivers was based on field visits during the year 2006. The field visits consisted of an inspection and collection of information to complete a database for obstacles and their associated fishways (Ordeix et al., 2006). A number of physical variables were assessed at each hydraulic device, including the average and maximum current velocity under different flow conditions, the operating levels of the fish pass, the height of fishway traverses (where present), and water depths. The old and new versions of the ICF index, which evaluate the degree 


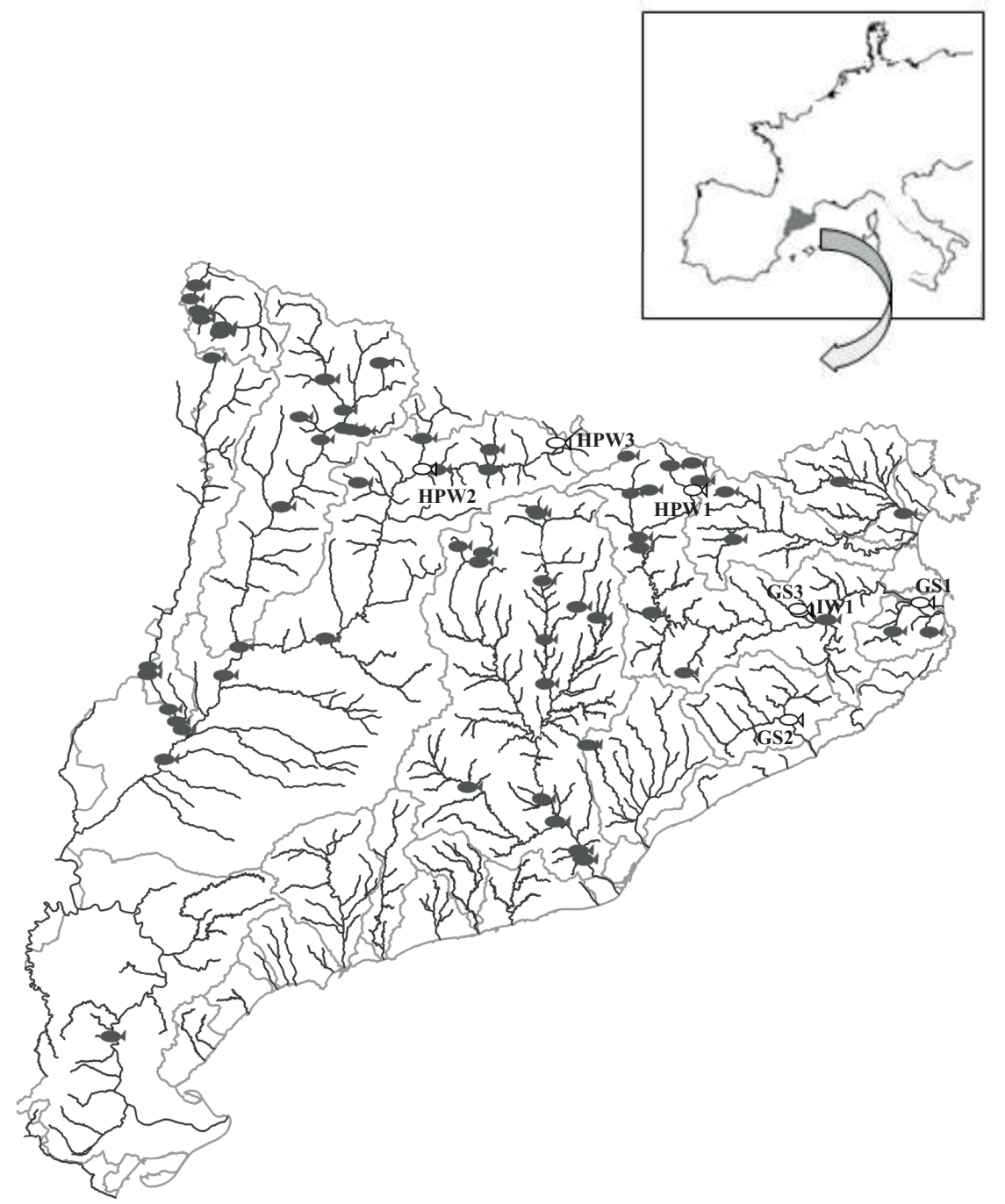

Figure 1. Fishways in the rivers of Catalonia (NE Iberian Peninsula) in 2006 showing the seven fish passes (white symbols) selected for in situ estimations of fish pass effectiveness. Soluciones de paso para peces existentes en los ríos de Catalunya (NE Península Ibérica) en el año 2006, mostrando los siete dispositivos de paso para peces (símbolos blancos) seleccionados para la evaluación in situ de su eficacia.

of impediment to fish passage (HIDRI protocolACA, 2006; Solà et al., 2011), were calculated for each of the 78 facilities. The ICF index is based on comparison between physical characteristics of the obstacle and the fish pass (if any) and the swimming and/or jumping skills of the potential fish fauna present in the river section evaluated. It enables the evaluation of river connectivity across a wide region including a large number of obstacles to be targeted and medium- to longterm monitoring once a solution to restore connectivity has been implemented. Additionally, the ICF index can be complementary to in situ estimations of fish crossing rates, as they both discriminate among infrastructures based on the chance they can be crossed by all species, only by some species, or by no species (Solà et al., 2011).

The ICF index was designed as part of the procedure to assess the hydromorphological quality of Catalan rivers for a preliminary evaluation of obstacle permeability and of the fish passes (if any) associated with the obstacle. The initial application of this index revealed deficiencies that led to a final result that did not coin- 
cide with the real longitudinal connectivity evaluated independently. However, this index has recently been updated and improved (new ICF version: Solà et al., 2011).

\section{Estimation of fish pass effectiveness}

Fish pass effectiveness was assessed using methods that allowed estimation of the barrier effect on fish species present between 2006 and 2009. The barrier effect was deducted from fish crossing rates, deviations of size frequencies in the water intake of the fish pass and downstream reach of the obstacle or deviations of size frequencies in reaches upstream and downstream of the obstacle (Lucas \& Baras, 2001; Roni, 2005). The evaluation of barrier effects was undertaken during high migration activity periods of the species expected to be present in each river stretch, so that the barrier effect was maximised. We assumed that a barrier effect would exist when fish crossing rates are different than the natural fish pass ability (assuming all sizes and species should be able to cross under natural conditions) and when deviations in size frequency distributions upstream and downstream of the obstacle are found.

Thus, our deduction of fish pass efficiency was based on estimating the barrier effects through deviations in crossing rates and in size class frequencies and followed the criteria below (equivalent to the same quality range for river connectivity within the new ICF index; Solà et al., 2011):

1. If all fish species and individuals present downstream of the obstacle can pass under nearly any hydrological situation and the fish species size frequencies downstream and upstream are equal, there is an absence of a barrier effect, representing natural conditions, and the fish pass effectiveness is of very good quality.

2. If the majority of the fish species and individuals present downstream of the obstacle can pass in nearly any hydrological situation and the fish species size frequencies downstream and upstream are similar, there is a small barrier effect, and fish pass effectiveness is good.
3. If the majority or some of the fish groups and individuals present downstream of the obstacle can pass, and the fish species size frequencies downstream and upstream are similar in any or in some hydrological conditions, there is a barrier effect indicating that the fish pass could be specific or not completely functional, and thus, fish pass effectiveness would be classified as moderate.

4. If only one or few species and individuals present downstream of the obstacle can pass and the fish species size frequencies downstream and upstream are different, there is a barrier effect indicating that the fish pass could be very specific or poorly functional, and thus, fish pass effectiveness would be classified as poor.

5. If none of the fish species or individuals present downstream of the obstacle can pass, or only some individuals can cross under very exceptional hydrological situations and the fish species size frequencies downstream and upstream are very different, there is a barrier effect indicating that the fish pass is nonexistent or non-functional, and thus, fish pass effectiveness would be classified as bad.

The application of different techniques to estimate fish crossing rates and deviations in size frequency was based on the type of fish community present and the characteristics of the studied river reach, obstacle and fishway (see below). For example, visual counts (Travade \& Larinier, 2002; Marmulla \& Welcomme, 2002) are limited by water turbidity and the presence of a large number of migrating fish. Therefore, this technique was only used at one site (GS1; in the low Ter River). Other direct estimation techniques included the installation of fish traps at the water intake upstream of the facility (Travade \& Larinier, 2002; Marmulla \& Welcomme, 2002; Clavero et al., 2006). The indirect estimation techniques used consisted of methods such as comparison of fish populations on both sides of the obstacle using electrofishing procedures (Santos et al., 2006). Thus, depletion sampling with three passes was performed using Erreka 
III (Acuitec, Euskadi, SP) equipment associated with a Honda GXV50 motor $(220 \mathrm{~V}, 50 \mathrm{~Hz}$ and 2,200 W: Lobón-Cerviá, 1991; Travade \& Larinier, 2002) at the seven sites. Additionally, fish trapping systems (Roni, 2005; Clavero et al., 2006; Travade \& Larinier, 2002) were employed at four sites (HPW2, HPW3, GS3 and IW1), while mark-recapture methods (Larinier et al., 1994; Amstrup et al., 2005) were used at one site (HPW1), and individual mark-recapture methods, using Passive Induction Transmitters (PIT tags; Roni, 2005; Amstrup et al., 2005) were used at two sites (GS3 and IW1).

Species composition and density and parameters such as size structure, cohort or age group and sex ratio were used to characterise the fish populations. At each site, the most abundant species were analysed to include a sufficient number of individuals to draw size distribution frequencies and perform statistical analyses. Deviations in the most abundant fish species size frequencies downstream and upstream of the obstacle or downstream and crossing the water intake upstream of the fish passes were analysed by means of a Chi-square test using the statistical package SPSS (for Windows, version 15.0, SPSS Inc., Chicago, Illinois).

\section{Study sites}

The 7 selected fish passes were located in weirs at hydropower plants and gauging stations: 4 in the Ter river basin, 2 in the Ebro river basin and 1 in the Tordera River (Fig. 1).

\section{Upper Ter River at the hydropower weir of} les Rocasses, in Camprodon (el Ripollès area) (HPW1)

The Rocasses weir is $17 \mathrm{~m}$ long and $2.3 \mathrm{~m}$ high. It is located in a river stretch associated with a extremely high density of weirs and other obstacles. The fish pass consists of a pool fish pass without small waterfalls inside a rock ramp. The fish pass is integrated into a rock ramp with a triple function: to ensure its structural strength at times of high flow, to achieve good landscape integration, and to permit the passage of semiaquatic animals (some macroinvertebrates, amphibians, reptiles and mammals). Fish crossing rates and size class frequencies were estimated through a combination of fish trapping at the water intake upstream of the facility, electrofishing upstream and downstream and group mark-recapture methods using a total of 3,000 fish tagged with acrylic paint. Surveys were performed during seven periods of ten days every two months in 2006/2007 (from February to February). A cross-section of the pass was completely blocked off using two special fish traps (each $7 \mathrm{~m}$ long with a $0.015-\mathrm{m}$ mesh size) with a tight connection to the bottom. The group mark-recapture method employed an acrylic paint injection system in the caudal fin of the fish. The fish caught on each side of the obstacle were marked with different colours (blue or red). This method does not cause infection, and there is no increase in mortality or decrease in physical capacity if the marked individuals are longer than $0.12 \mathrm{~m}$. Mark-recapture models (Larinier et al., 1994) allow estimation of fish crossing rates between two fisheries as the percentage of units located downstream of the device to travel upstream of the device during this period. Application of group markrecapture methods has enabled the calculation of fish crossing rates for trout.

\section{Lower Ter River at the Torroella de Montgri Bridge gauging station (EA080) (el Baix Em- pordà area) (GS1)}

The Torroella de Montgrí bridge base is $125 \mathrm{~m}$ long and $1 \mathrm{~m}$ high and is the first significant obstacle for fish migrating upstream from the sea in the Ter River, in addition to being associated with frequent low flow conditions. The fish pass is a pool pass integrated into a gauging station. It includes traverses of variable size, mainly less than $0.25 \mathrm{~m}$ in height, although there are some higher than $0.6 \mathrm{~m}$. At this site, fish crossing rates were estimated using fish trapping at the water intake upstream of the facility and by performing visual counts, while the size class frequencies upstream and downstream of the obstacle were estimated by electrofishing. Two special fish traps $(2 \times 0.8 \mathrm{~m}$ rectangular stainless 
steel squares, $7 \mathrm{~m}$ long and with a $1.5-\mathrm{cm}$ mesh size) were installed immediately upstream of the two water intakes upstream of the facility. Visual counts consisted of 10-minute censuses repeated every 1.5 hours throughout a day. Total counts were performed from a point with an optimal viewing angle, supported by digital video recording to validate the visual counts. This method is efficient for medium-sized or large fish (total length greater than $0.2 \mathrm{~m}$ ).

\section{Upper Segre River (Ebro River basin) at the Olympic channel of la Seu d'Urgell hydropower weir (l'Alt Urgell area) (HPW2)}

This weir is $70 \mathrm{~m}$ long and $1 \mathrm{~m}$ high. The fish passage is a broad-spectrum technical pool pass. Its traverses are only $0.1 \mathrm{~m}$ in height, and the pass is only $0.75 \mathrm{~m}$ wide. Fish crossing rates and size class frequencies were estimated by combining fish trapping at the water intake upstream of the facility and electrofishing upstream and downstream of the obstacle, respectively. Surveys occurred in 2008 (April, July and November) in three-week periods every three months. A fish trapping campaign was conducted during each monitoring period simultaneously using two kinds of fish traps without bait: camaronera $(2 \mathrm{~m}$ long, 0.006-m mesh size) and anguilera $(3.5 \mathrm{~m}$ long, 0.01-m mesh size). However, electrofishing was only performed in July because of the existence of many deep pools.

\section{Aravó stream (Ebro River basin) in Puigcerdà hydropower weir (la Cerdanya area) (HPW3)}

This weir is $40 \mathrm{~m}$ long and $1 \mathrm{~m}$ high. The fishway is a broad-spectrum technical structure consisting of a deflector with $0.20 \mathrm{~m}$ high baffles. Fish crossing rates and size class frequencies were estimated through a combination of fish trapping at the water intake upstream of the facility and electrofishing upstream and downstream of the obstacle, respectively. Surveys occurred in 2008 (April, July and November) in three-week periods every three months. A fish trapping campaign was performed in each monitoring period with an anguilera trap $(3.5 \mathrm{~m}$ long with a mesh of $0.01 \mathrm{~m})$.
However, electrofishing was only conducted in July because of the existence of many deep pools.

\section{Low Tordera River at the Fogars de la Selva} gauging station (EA089) (la Selva area) (GS2)

The Tordera's river gauging station is $72 \mathrm{~m}$ long and $0.5 \mathrm{~m}$ high. It is the first important obstacle in this river for fish coming upstream from the sea. The fish pass is a ramp integrated into the gauging station. This river reach dries up every year for a duration ranging from several weeks to several months in summer, and low flow conditions $\left(<0.5 \mathrm{~m}^{3} \mathrm{~s}^{-1}\right)$ dominate during the rest of the year, although there are also flood periods. Monitoring was undertaken immediately after the high flood period $\left(>10 \mathrm{~m}^{3} \mathrm{~s}^{-1}\right)$. Fish crossing rates and size class frequencies were estimated through a combination of fish trapping at the water intake upstream of the facility and electrofishing upstream and downstream of the obstacle, respectively. Surveys were performed in 2007 (May) and 2008 (April) in two periods of seven days per year involving the installation of two special fish traps $(2 \times 0.8 \mathrm{~m}$ rectangular stainless steel square, $7 \mathrm{~m}$ long with a $1.5-\mathrm{cm}$ mesh size) immediately upstream of the two water intakes upstream of the facility and electrofishing upstream and downstream of the obstacle.

\section{6-7. La Llémena stream (Ter River basin) at the} Ginestar de Llémena, Sant Gregori gauging station (EA009) (GS3) and the Sant Gregori gardens irrigation weir (el Gironès area) (IWI)

The gauging station weir is $6.5 \mathrm{~m}$ long and 1 $\mathrm{m}$ high. It includes a passage system consisting of a broad-spectrum technical pool fish pass with 7 traverses between 0.1 and $0.2 \mathrm{~m}$ high. The depth of the fish pass pools was improved in 2009, and a complementary concrete eel ramp was also constructed. The Sant Gregori irrigation weir, located $600 \mathrm{~m}$ downstream of the gauging station, is $7 \mathrm{~m}$ long and $2 \mathrm{~m}$ high. The passage system is a close-to-nature fish pass consisting of a natural fish ramp with a $5 \%$ slope. At this site, the fish crossing rates and size class frequencies were estimated by combining fish trap- 
ping at the water intake upstream of the facilities, electrofishing upstream and downstream and marking with individual mark-recapture methods (PIT tags). Application of individual markrecapture methods enabled the calculation of specific fish crossing rates. Surveys were conducted in 2008/2009 (from March to Novem- ber) in five periods of twelve days every four months. Moreover, an additional campaign of fish trapping upstream and downstream of the obstacle was performed to increase the fish catch for tagging in July 2008.

Micromarks consisting of PIT tags (diameter: $0.002 \mathrm{~m}$, length: $0.012 \mathrm{~m}$ and frequency:

Table 1. Existing typologies of fish passes or fishways in the rivers of Catalonia in 2006 (Ordeix et al., 2006). Tipologías de dispositivos o soluciones de paso para peces existentes en los ríos de Catalunya en 2006 (Ordeix et al., 2006).

\begin{tabular}{|c|c|c|c|c|}
\hline \multicolumn{4}{|c|}{ Solutions } & \multirow{2}{*}{$\frac{\text { Number }}{\text { Not considered }}$} \\
\hline \multirow{5}{*}{ Restoration } & \multicolumn{3}{|c|}{ Improvement of water quality } & \\
\hline & Improvement of $r$ & bitat quality & & Not considered \\
\hline & Total obstacle ren & \multirow{3}{*}{\multicolumn{2}{|c|}{ Subtotal }} & 0 \\
\hline & \multirow[t]{2}{*}{ Partial obstacle removal } & & & 14 \\
\hline & & & & 14 \\
\hline \multirow{22}{*}{ Rehabilitation } & \multirow{14}{*}{$\begin{array}{l}\text { Fish pass } \\
\text { solutions }\end{array}$} & \multirow{3}{*}{$\begin{array}{l}\text { Close-to-nature } \\
\text { solutions }\end{array}$} & Bottom ramps or rock ramps & 1 \\
\hline & & & Bypass channels or streams & 0 \\
\hline & & & Fish ramps & 5 \\
\hline & & & Pool fish passes & 30 \\
\hline & & Broad-spectrum & Pool fish passes without drops & 1 \\
\hline & & solutions & Slot passes or vertical slot fishways & 5 \\
\hline & & & Deflectors & 8 \\
\hline & & & Denil or baffle fish passes & 2 \\
\hline & & Mechanical or & Eel ladders & 0 \\
\hline & & specific & Fish locks & 0 \\
\hline & & technical & Fish lifts & 2 \\
\hline & & & Siphons and fish pumps & 0 \\
\hline & & $\begin{array}{l}\text { Other solutions } \\
\text { not considered } \\
\text { effective }\end{array}$ & “Stairs" & $\begin{array}{l}6 \\
4\end{array}$ \\
\hline & & & Subtotal & 64 \\
\hline & \multirow{4}{*}{$\begin{array}{l}\text { Systems for fish } \\
\text { protection }\end{array}$} & \multirow{3}{*}{\multicolumn{2}{|c|}{$\begin{array}{l}\text { Mechanical barriers } \\
\text { Electrical barriers } \\
\text { Light barriers }\end{array}$}} & - \\
\hline & & & & 0 \\
\hline & & & & 0 \\
\hline & & & Subtotal & $\mathbf{0}$ \\
\hline & \multirow{5}{*}{$\begin{array}{l}\text { Adjusted } \\
\text { management }\end{array}$} & \multicolumn{2}{|c|}{ Environmental flows } & Not considered \\
\hline & & \multicolumn{2}{|c|}{ Regulation or protection sluices } & 0 \\
\hline & & \multicolumn{2}{|c|}{ Shipping locks } & 0 \\
\hline & & & Subtotal & 0 \\
\hline & & & Total & 78 \\
\hline
\end{tabular}


$134.2 \mathrm{kHz}$ ) with individual alphanumeric codes were inserted into the peritoneal cavities of 1133 fishes (1023 Western Mediterranean barbels, 80 Ebro barbels and 30 eels). We marked Western Mediterranean barbels (Barbus meridionalis) with minimum length of $0.09 \mathrm{~m}$, Ebro barbels (Luciobarbus graellsii) larger than $0.1 \mathrm{~m}$ and European eel (A. anguilla) larger than $0.3 \mathrm{~m}$. Fixed receivers (square antennae of $0.30 \times 0.80 \mathrm{~m}$ ) identified fish individually and continuously and allowed us to obtain information regarding when they advanced to the upstream exit of the fish pass. In addition, portable receivers allowed identification of each tagged fish when it was recaptured using the incorporated encoded chip. At these sites, it was possible to estimate fish passage rates for each species, which was also weighted by population size using the results from the depletion electrofishing survey. Moreover, identification of each marked specimen within the fish passage device provided information on the phenology of fish migration and biometric characteristics of individuals that successfully used the fishway.

\section{RESULTS}

\section{Characterisation and rapid evaluation of fish passes}

Seventy-eight fishways were identified in over a thousand obstacles in Catalan rivers up to 2006. These were mostly located in the upper parts of the Ebro, Garona, Ter and Llobregat river catchments (29, 23, 12 and 9 fishways, respectively (Fig. 1). Most of them (90\%) were designed to improve brown trout (S. trutta) fisheries. Fourteen fish passages $(18 \%)$ were classified as restoration solutions (partial weir removals), all of which were located in the Aran valley (Pyrenees), while more than half, 64 (54\%), were rehabilitation solutions that used pool and vertical slot fishways. Six obstacles $(8 \%)$ were closeto-nature fish passes (ramps), and 10 (13\%) were baffle fish passes (see Solà et al., 2011), while only 2 fish lifts $(3 \%)$ and 4 smooth ramps $(5 \%)$ were observed (Table 1$)$.
Table 2. Fish passes or fishways in the rivers of Catalonia in 2006 (Ordeix et al., 2006) classified using the old (ICFO) and new (ICFN) versions of the ICF index. Dispositivos $o$ soluciones de paso para peces de los ríos de Catalunya en 2006 (Ordeix et al., 2006) clasificados utilizando las versiones antigua (ICFO) y nueva (ICFN) del índice ICF.

\begin{tabular}{lccccc}
\hline & $\begin{array}{c}\text { ICF category } \\
\text { Facilities }\end{array}$ & $(\boldsymbol{\%})$ & Facilities & $(\boldsymbol{\%})$ & \\
\hline I & HIGH & - & - & 17 & 21.8 \\
\hline II & GOOD & 3 & 3.9 & 10 & 12.8 \\
\hline III & MODERATE & 16 & 20.5 & 15 & 19.2 \\
\hline IV & POOR & 11 & 14.1 & 11 & 14.1 \\
\hline V & BAD & 48 & 61.5 & 25 & 32.1 \\
\hline
\end{tabular}

Using the old ICF index, over half of the barriers were classified as poor quality, despite the existence of fish passage devices, and only 9 were assessed as functional, whereas only a third were included in this poor quality class when using the new version (Table 2). Moreover, none of the obstacles were included in the very good class, and only $4 \%$ were classified as presenting good connectivity when using the old version. However, the new ICF version included $20 \%$ of the obstacles in the very good quality class, and $13 \%$ were classified as exhibiting good connectivity, being either partial barriers, only small-scale structures, or close-to-nature fish facilities (Table 2).

\section{Assessment of the effectiveness of 7 fish passes}

\section{1. $H P W 1$}

Here, the fish community consisted of brown trout ( $S$. trutta) and Western Mediterranean barbel (B. meridionalis). Although the Ebro chub (Squalius laietanus) and European eel (A. anguilla) potentially exist in this reach, they were not found in this study. There were no alien fish species observed. The passage of brown trout exhibited a maximum rate in autumn $(2.0-5.7$ individuals day $^{-1} ; 0.7-1.9 \%$ of the total migrators day $^{-1}$ ), was lower in summer (1.9 ind. day ${ }^{-1}$; $0.8 \%$ of the total migrators day $^{-1}$ ) and lowest in winter (0-1.2 ind. day ${ }^{-1} ; 0-1.4 \%$ of the tot. migr. day $\left.{ }^{-1}\right)$ and spring (0.2 ind. day $^{-1} ; 0.1 \%$ of the tot. migr. day $\left.{ }^{-1}\right)$. Important movements 

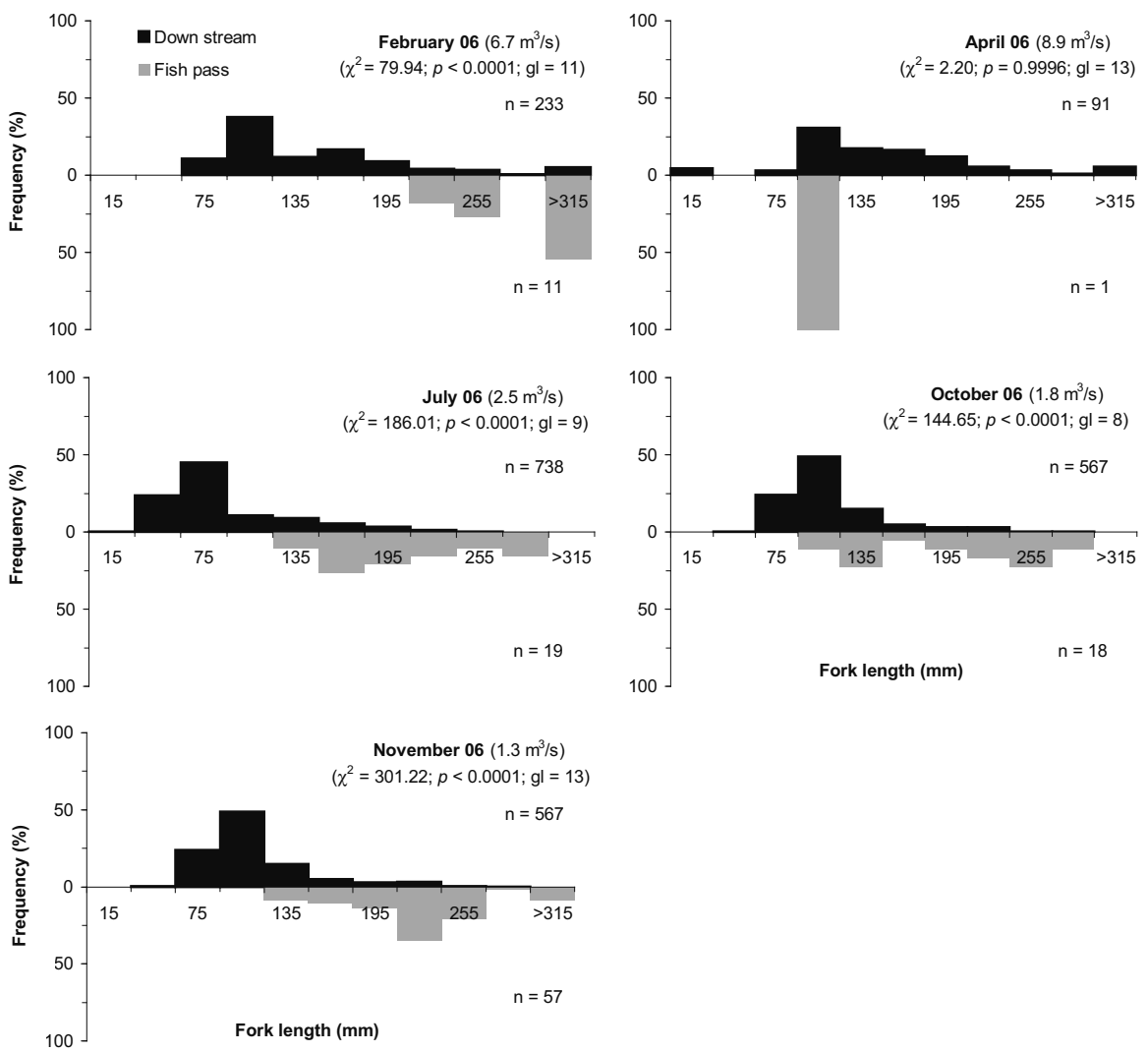

Figure 2. Brown trout (Salmo trutta) size class frequencies (fork length, mm) downstream and in the water intake upstream of the fish pass of les Rocasses hydropower weir (HPW1) at the upper Ter River in Camprodon (el Ripollès area, Catalonia) from February to November 2006. Flow data for each season and Chi-square test results are also shown. Frecuencias de tallas de trucha (Salmo trutta) -longitud furcal ( $\mathrm{mm}$ - aguas abajo y en la entrada del agua (aguas arriba) al dispositivo de paso para peces del azud hidroeléctrico de les Rocasses (HPWI), en el curso alto del río Ter en Camprodon (comarca del Ripollès, Catalunya), desde febrero a noviembre de 2006. También se muestran los datos de caudales para cada estación y los resultados del test Chi-cuadrado.

of trout were mostly associated with the spawning period (around November) and the period just after a high flow $\left(60 \mathrm{~m}^{3} \mathrm{~s}^{-1}\right.$ in February 2006; crossing rate of $1.4 \%$ of the total migrants

day $^{-1}$ during next week). This hydropower station (with fish pass) had a clear barrier effect for most of the young-of-the-year fish (YOY; fork length: FL <0.15 m; Fig. 2). Moreover, only the
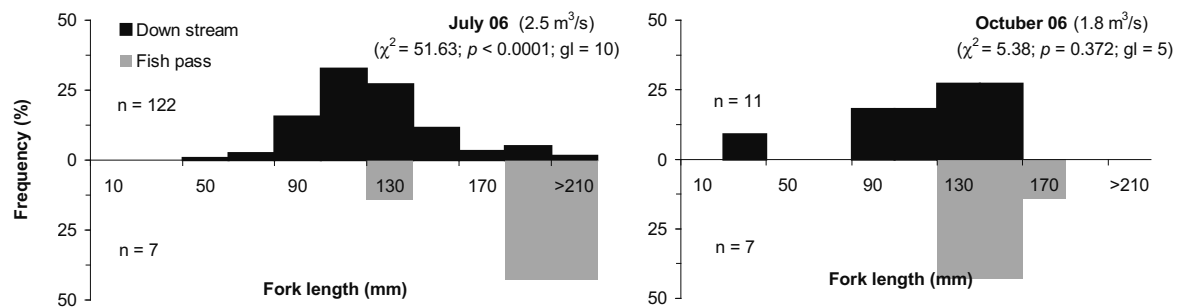

Figure 3. Western Mediterranean barbel (Barbus meridionalis) size class frequency (fork length, $\mathrm{mm}$ ) downstream and in the water intake upstream of the fish pass of les Rocasses hydropower weir (HPW1) at the upper Ter River in Camprodon (el Ripollès area, Catalonia) in July and October 2006. Estimated flow data for each season and Chi-square test results are also shown. Frecuencias de tallas de barbo de montaña (Barbus merdionalis) -longitud furcal ( $\mathrm{mm}$ - aguas abajo y en la entrada del agua (aguas arriba) al dispositivo de paso para peces del azud hidroeléctrico de les Rocasses (HPW1), en el curso alto del río Ter en Camprodon (comarca del Ripollès, Catalunya), en julio y octubre de 2006. También se muestran los datos de caudales para cada estación y los resultados del test Chi-cuadrado. 

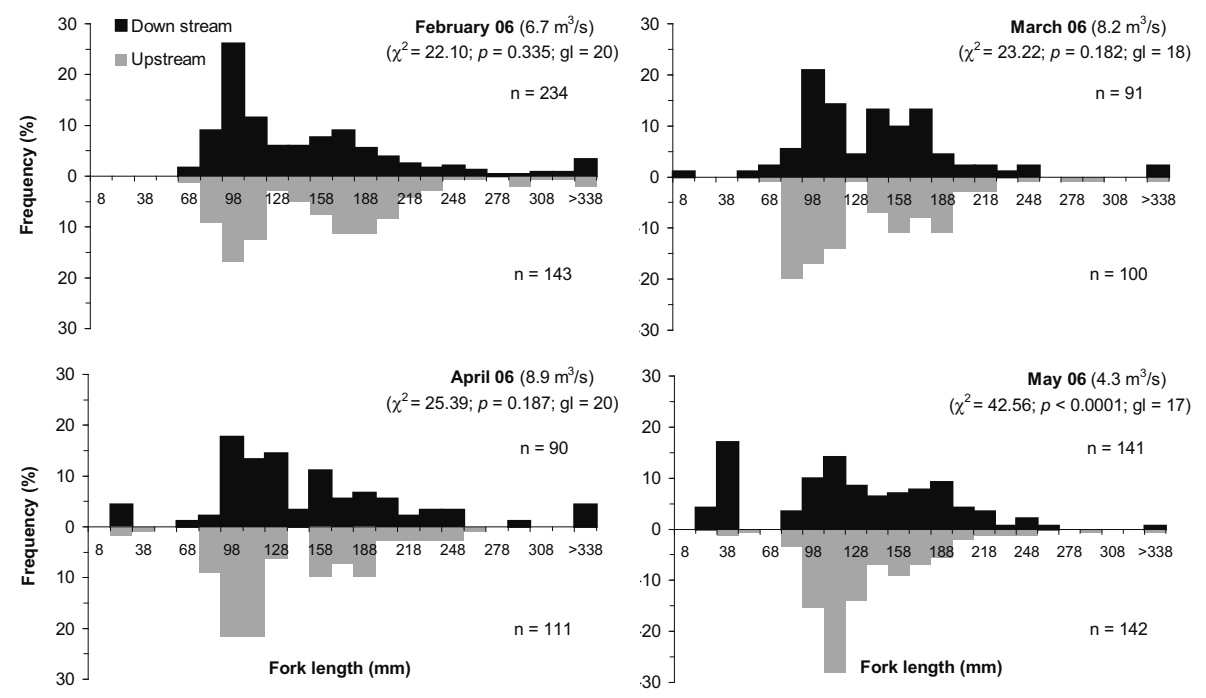

Figure 4. Brown trout (S. trutta) size class frequencies (fork length, mm) downstream and upstream of the fish pass of les Rocasses hydropower weir (HPW1) at the upper Ter River in Camprodon (el Ripollès area, Catalonia) from February to May 2006. Estimated flow data for each season and Chi-square test results are also shown. Frecuencias de tallas de trucha (S. trutta)-longitud furcal (mm) aguas abajo y aguas arriba del dispositivo de paso para peces del azud hidroeléctrico de les Rocasses (HPW1), en el curso alto del río Ter en Camprodon (comarca del Ripollès, Catalunya), entre febrero y mayo de 2006. También se muestran los datos de caudales para cada estación y los resultados del test Chi-cuadrado.

largest Western Mediterranean barbel individuals $(\mathrm{FL}>0.13 \mathrm{~m})$ were able to cross upstream, most of which were females; the differences of fish structure between each side of the barrier were significant, except in October (Fig. 3). Furthermore, comparison of the size structure of brown trout on each side of the barrier did not indicate significant differences, except in May (Fig. 4). Fish pass effectiveness at this obstacle was considered moderate.

\section{GS1}

The fish community in this river section was composed of Mediterranean mullets (Liza ramada, Mugil cephalus and Chelon labrosus), freshwater blenny (Salaria fluviatilis) and European eel (A. anguilla). Ten alien species, including Ebro barbel (L. graellsii), were also present. Only large mullet and Ebro barbel (minimum size is FL $>0.55 \mathrm{~m}$ ) individuals could cross upstream in spring after moderate floods (approximately $10 \mathrm{~m}^{3} \mathrm{~s}^{-1}$ ) with a moderate water velocity inside the fish pass $\left(<1.4 \mathrm{~m} \mathrm{~s}^{-1}\right)$ and when water temperature was above $10^{\circ} \mathrm{C}$. The average fish crossing rate was at a minimum $\left(0\right.$ ind. day $\left.^{-1}\right)$ from January to March and moderate from April to September (maximum of 82 mullet day $^{-1}$ and 4 Ebro barbel day $\left.{ }^{-1}\right)$. Visual counts revealed major activity early in the morning and in the afternoon. Visual observations also showed a high concentration of glass eel downstream of this barrier, although some of these individuals might be able to migrate through the bridge base. According to these results, the fish pass effectiveness in this obstacle has been considered moderate; only some of the fish groups and individuals present downstream of the obstacle can pass in any hydrological conditions, although the fish species size frequencies downstream and upstream are similar. Thus, there exists a barrier effect that indicates that this fish pass might not be completely functional.

\section{HPW2}

The fish community here consisted of brown trout (S. trutta), Ebro barbel (L. graellsii), Iberian redfin barbell (Barbus haasi), Ebro chub (S. laietanus), Ebro nase (Parachondrostoma miegii), Pyrenean gudgeon (Gobio lozanoi), Pyrenean minnow (Phoxinus bigerri) and Pyrenean stone loach 

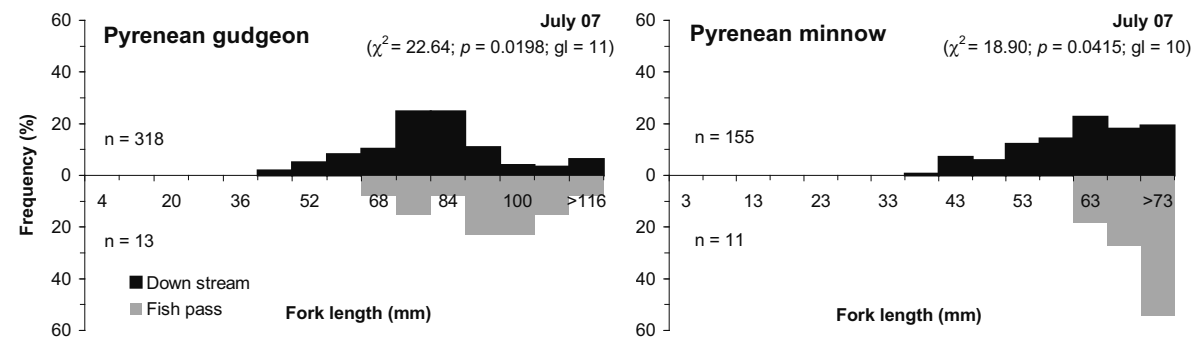

Figure 5. Pyrenean gudgeon (Gobio lozanoi) and Pyrenean minnow (Phoxinus bigerri) size class frequencies (fork length, mm) downstream and in the water intake upstream of the fish pass of the Olympic channel of la Seu d'Urgell hydropower weir (HPW2) at the upper Segre river (Ebro River basin; l'Alt Urgell area, Catalonia) in July 2007. Chi-square test results are also shown. Frecuencias de tallas de gobio (Gobio lozanoi) y foxino (Phoxinus bigerri) -longitud furcal ( $\mathrm{mm}$ )- aguas abajo y en la entrada del agua (aguas arriba) al dispositivo de paso para peces del azud de la central hidroeléctrica del Canal Olímpico de la Seu d'Urgell (HPW2), en el curso alto del río Segre (cuenca del río Ebro, comarca del Alt Urgell, Catalunya), en julio de 2007. También se muestran los resultados del test Chi-cuadrado.

(Barbatula guinardi). European eel (A. anguilla) and other native species may also be present. There were only few individuals of alien fish species found. The maximum passage rate at this location was observed during July (16 ind. day $\left.{ }^{-1}\right)$ and was directly related to the maximum activity of cyprinid species, warm water temperature $\left(18.7^{\circ} \mathrm{C}\right)$, low water velocity inside the fishpass (max. of $0.5 \mathrm{~m} \mathrm{~s}^{-1}$ ) and the largest change in the river flow observed (from $0.04 \mathrm{~m}^{3} \mathrm{~s}^{-1}$ on $07 / 07 / 03$ to $0.3 \mathrm{~m}^{3} \mathrm{~s}^{-1}$ on $07 / 07 / 05$ ), which was related to the management of the flows of the hydropower plant. The minimum passage rate (zero) occurred during November and was related to a very low flow in the river $\left(0.03 \mathrm{~m}^{3} \mathrm{~s}^{-1}\right)$. In April, an intermediate passage rate was observed (5.5 ind. day ${ }^{-1}$ ). Most of the fish species and individuals present can use the existing fish pass, as can species of smaller size, such as the Pyrenean gudgeon and Pirenean minnow, although in both cases, there appears to be a significant barrier effect for the smaller size classes (Fig. 5). Fish pass effectiveness at this obstacle has been considered moderate.

\section{4. $H P W 3$}

The fish community here consisted of brown trout (S. trutta), Pyrenean gudgeon (G. lozanoi) and Pyrenean stone loach (B. guinardi). No alien fish species were observed. Brown trout dominated this river stretch in terms of the number of individuals and always represented more than
$92 \%$ of the total catches. The average rate of brown trout passage was $<1.5$ ind. day ${ }^{-1}$, for periods with low water velocities inside the fishpass (max. of $0.5 \mathrm{~m} \mathrm{~s}^{-1}$ in April and 0.85 in July), and it was zero in November, when there was a moderate water velocity inside the fish pass (max. of $1.41 \mathrm{~m} \mathrm{~s}^{-1}$ ). The fish pass located at this weir permits upstream migration of brown trout, although a portion of the young-of-theyear (FL > 0.10 m; Fig. 6) cannot cross upstream,

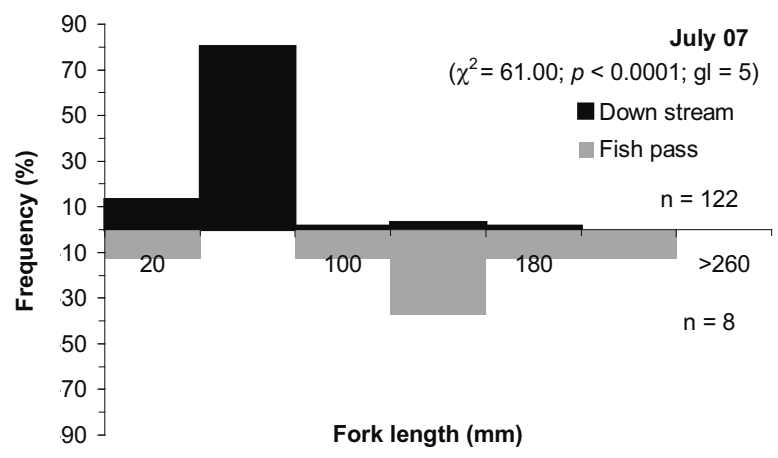

Figure 6. Brown trout $(S$. trutta) size class frequencies (fork length, $\mathrm{mm}$ ) downstream and in the water intake upstream of the fish pass of the Reial Club de Golf de la Cerdanya hydropower weir (HPW3) at Aravó stream in Puigcerdà (Ebro River basin; Segre River sub basin; la Cerdanya area, Catalonia) in July 2007. Chi-square test results are also shown. Frecuencias de tallas de trucha (S. trutta)-longitud furcal ( $\mathrm{mm}$ ) - aguas abajo y en la entrada del agua (aguas arriba) al dispositivo de paso para peces del azud del Reial Club de Golf de la Cerdanya (HPW3), en el río Aravó en Puigcerdà (cuenca del río Ebro, subcuenca del río Segre; comarca de la Cerdanya, Catalunya) en julio de 2007. También se muestran los resultados del test Chi-cuadrado. 
even under low flow conditions $\left(<0.1 \mathrm{~m}^{3} \mathrm{~s}^{-1}\right)$. Furthermore, comparison of the size structure of brown trout on each side of the barrier did not indicate significant differences. According to these results, the fish pass effectiveness at this obstacle has been considered good; the major- ity of the fish species and individuals present downstream of the obstacle can pass in nearly any hydrological situation, and fish species size frequencies downstream and upstream are similar. Taken together, these findings indicate that a small barrier effect exists.

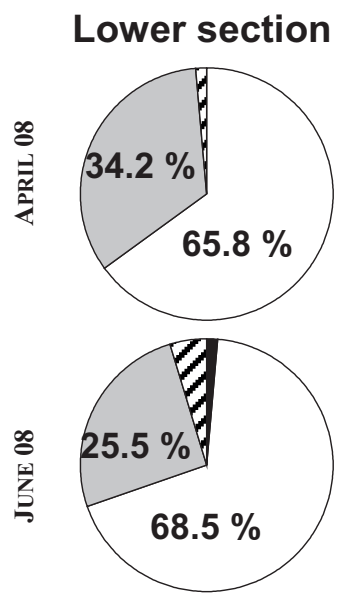

\section{Central section}
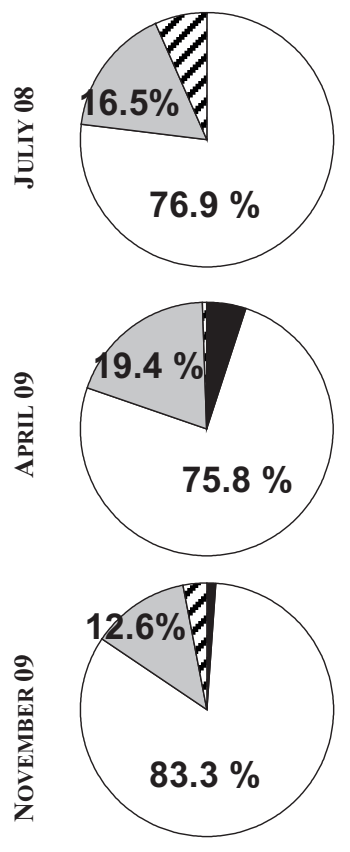

Eel
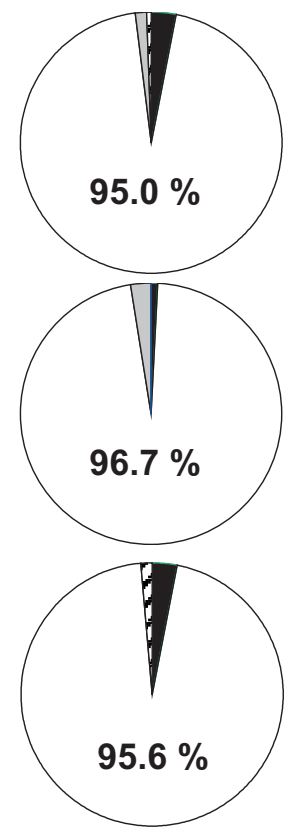

\section{Upper section}
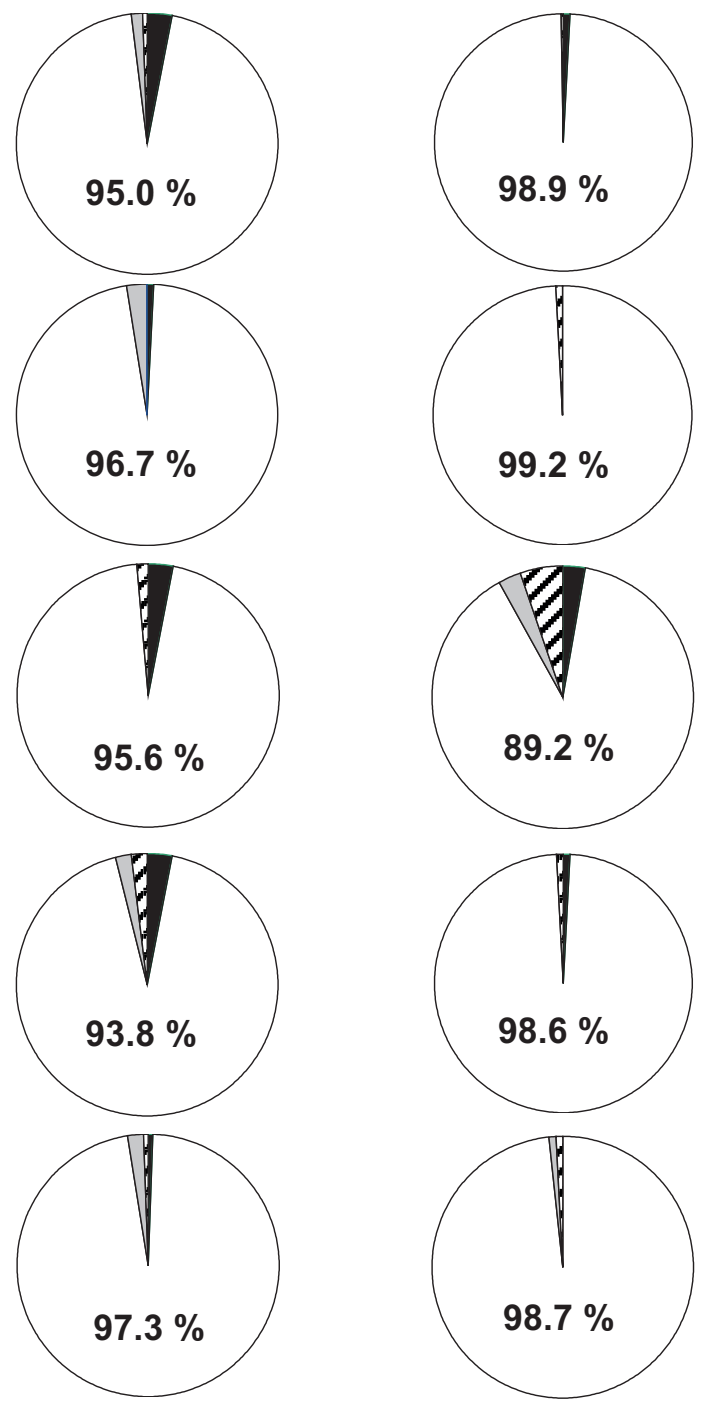

$\square$ Ebro barbel

$\square$ Trout

Figure 7. Fish species catch proportions upstream of the Ginestar de Llémena EA009 gauging station (GS3) (upper section) between GS3 and the Sant Gregori irrigation weir (IW1) (Central section) and downstream of this irrigation weir (Lower section) at Llémena stream in Sant Gregori (Ter River basin; el Gironès area, Catalonia) during 2008 and 2009. Proporción de capturas por especie de pez aguas arriba de la estación de aforo EA009 de Ginestar de Llémena (GS3) (tramo superior), entre esta y el azud para riego de las huertas de Sant Gregori (IW1) (tramo central) y aguas abajo del azud para riego (tramo inferior), en el río Llémena en Sant Gregori (cuenca del río Ter; comarca del Gironès, Catalunya) durante 2008 y 2009. 


\section{GS2}

The fish community here consisted of Western Mediterranean barbel (B. meridionalis), Ebro chub (S. laietanus), mullets (L. ramada, M. cephalus and C. labrosus) and European eel (A. anguilla). Many alien species were also present at high abundances. The upstream migration rates of Western Mediterranean barbel and European chub were 1.4 individuals day ${ }^{-1}$ in May and April of consecutive years, coinciding with high cyprinid activity and with a moderate water velocity inside the fish pass (max. of $1.9 \mathrm{~m} \mathrm{~s}^{-1}$ in April) just after high flows $\left(>10 \mathrm{~m}^{3} \mathrm{~s}^{-1}\right)$. Eels were not observed to cross the fish pass, and this specie was very rare upstream. The fish pass effectiveness at this obstacle has been considered moderate. Only some of the fish groups and individuals present downstream of the obstacle can pass in any hydrological condition, although the fish species size frequencies downstream and upstream are similar. There is a barrier effect indicating that this fish pass might not be completely functional.

\section{6-7. GS3 and IWI}

This fish community was dominated by Western Mediterranean barbel (B. meridionalis) and also included European eel (A. anguilla) and Ebro chub (S. laietanus). Ebro barbel (L. graellsii) and brown trout $(S$. trutta) were the only non-native species present in this stretch. The relative abundance of Western Mediterranean barbel varied depending on the sector and season (Fig. 7); it almost always represented more than $95 \%$ of the catch upstream of GS3 (upper section) and between GS3 and IW1 (central section). In contrast, its relative abundance is lower downstream of the irrigation weir (lower section), mainly due to the presence of Ebro barbel, which represents between $34 \%$ (April 2008) and $12.6 \%$ (November 2009) of the catch. Moreover, Ebro barbel appeared in the upstream section after the construction of the new fish pass into the gauging station (July 2008, Fig. 7). Eel and brown trout present very low, but stable densities in all three sectors, whereas Ebro chub appears only sporadically.

The fish passage rates in the GS3 pool pass were high or moderate associated with a high water velocity inside the fish pass (max. $2.4 \mathrm{~m} \mathrm{~s}^{-1}$ in June 2008) and warm water $\left(16.8^{\circ} \mathrm{C}\right.$ in June 2008 and $15.1^{\circ} \mathrm{C}$ in October 2008), whereas they were low in April and November. Important movements of Western Mediterranean barbel, Ebro barbel and Ebro chub were mostly associated with the spawning period (around June), and upstream migration of brown trout was also associated with the spawning period (in November). The fish pass located at the gauging station permits upstream migration of the majority of fish species and individuals present downstream of the obstacle. However, medium and large Western Mediterranean barbel (FL $>0.04 \mathrm{~m}$; Fig. 8 and Fig. 9), mostly females, show significant positive selection with respect to moving upstream across the fish pass. In addition, the IW1
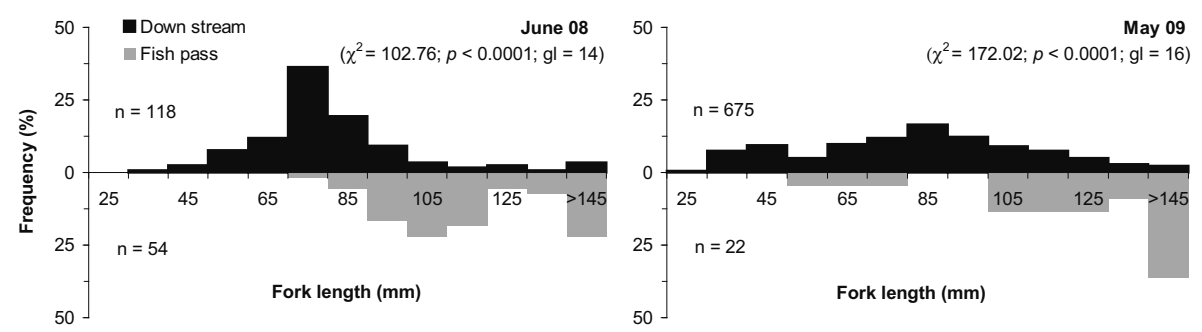

Figure 8. Western Mediterranean barbel (B. meridionalis) size class frequency (fork length, mm) downstream and in the water intake upstream of the fish pass of the Ginestar de Llémena EA009 gauging station (GS3) at Llémena stream in Sant Gregori (Ter River basin; el Gironès area, Catalonia) in the spring of 2008 and 2009. Chi-square test results are also shown. Frecuencias de tallas de barbo de montaña (B. merdionalis) -longitud furcal ( $\mathrm{mm}$ ) - aguas abajo y en la entrada del agua (aguas arriba) al dispositivo de paso para peces de la estación de aforo EA009 de Ginestar de Llémena (GS3) en el río Llémena en Sant Gregori (cuenca del río Ter; comarca del Gironès, Catalunya) en primavera de 2008 y 2009. También se muestran los resultados del test Chi-cuadrado. 

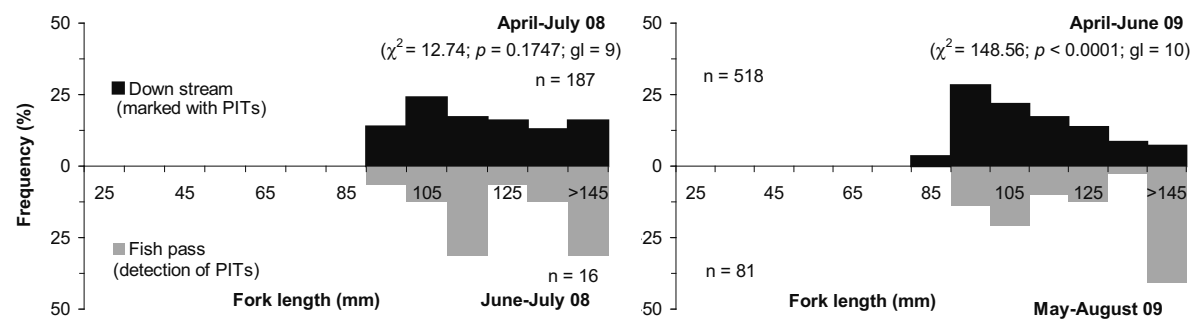

Figure 9. Western Mediterranean barbel (B. meridionalis) size class frequency (fork length, mm) of individuals with PIT tags detected downstream and in the water intake upstream of the fish pass of the Ginestar de Llémena EA009 gauging station (GS3) at Llémena stream in Sant Gregori (Ter River basin; el Gironès area, Catalonia) in the spring of 2008 and 2009. Chi-square test results are also shown. Frecuencias de tallas de barbo de montaña (B. merdionalis) -longitud furcal (mm)- marcados con PIT tags, detectados aguas abajo y en la entrada del agua (aguas arriba) al dispositivo de paso para peces de la estación de aforo EA009 de Ginestar de Llémena (GS3) en el río Llémena en Sant Gregori (cuenca del río Ter; comarca del Gironès, Catalunya) en primavera de 2008 y 2009. También se muestran los resultados del test Chi-cuadrado.

weir allows a large proportion of fish to migrate upstream under any flow conditions associated with a low water velocity (Fig. 9) being found inside its fish ramp (max. $0.9 \mathrm{~m} \mathrm{~s}^{-1}$ ). This obstacle (IW1) is only an important barrier for fish under conditions of very low flows $\left(<0.06 \mathrm{~m}^{3} \mathrm{~s}^{-1}\right)$.

The fish pass effectiveness at GS3 and IW1 has been considered good; the majority of the fish species and individuals present downstream of these obstacles can pass in nearly any hydrolog- ical situation, and the fish species size frequencies downstream and upstream are similar. Thus, there are small barrier effects here.

\section{Comparison of fish pass efficiency and ICF results}

The observed fish pass efficiency agrees with the results of the new version of the ICF index (Table 3). Only a small difference is observed at

Table 3. Selection of fish passes from the rivers of Catalonia for evaluating fish pass efficiency (Ordeix et al., 2009b). The most important characteristics, including obstacle type, pass type, monitoring techniques used, in situ fish pass efficiency (FPE), the old (ICFO) and new (ICFN) versions of the ICF index (Solà et al., 2011) and differences between the FPE and ICFO and ICFN results, are also shown $(1=\mathrm{Bad}, 2=$ Poor, 3 = Moderate, $4=$ Good and $5=$ Natural conditions $)$. Selección de los dispositivos de paso para peces de los ríos de Catalunya para evaluar su eficacia (Ordeix et al., 2009b). También se muestran las características más importantes, tales como el tipo de obstáculo, tipo de dispositivo de paso, técnicas de monitoreo utilizadas, evaluación de la eficiencia in situ (FPE), cálculo de la antigua (ICFO) y nueva versión (ICFN) del índice ICF (Solà et al., 2011) y diferencias de resultados entre FPE y ICFO y ICFN ( 1 = Mala, 2 = Deficiente, $3=$ Mediocre, $4=$ Buena y $5=$ Condiciones naturales $)$.

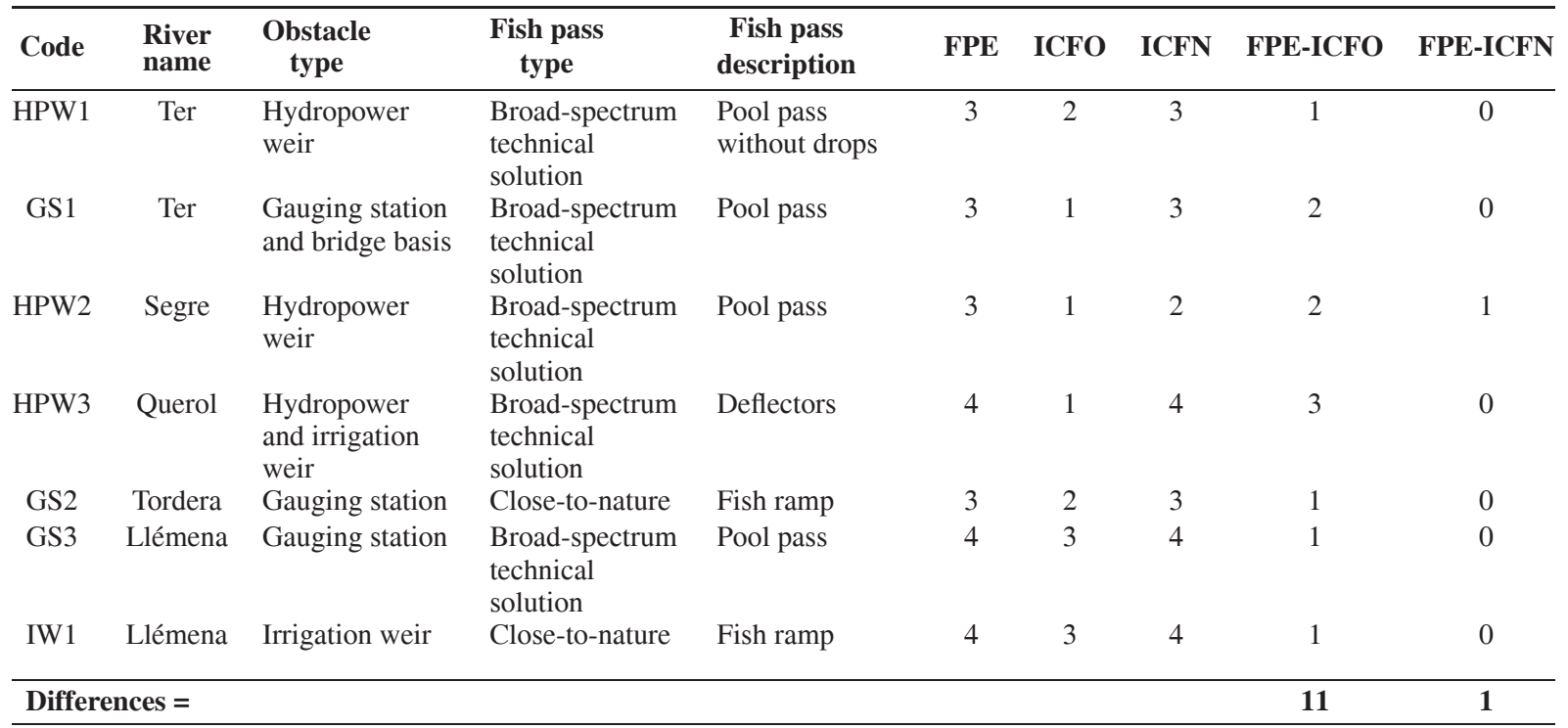


the HPW2 site, where fish pass efficiency has been classified as moderate, but the result of the new ICF index is poor. However, the evaluation of longitudinal connectivity using the old version of the ICF index does not correspond to the fish pass efficiency at any of the 7 fish passes evaluated (Table 3). Quick assessment procedures always underestimate in situ fish pass efficiency (positive results for differences between the FPE and ICF results, Table 3), especially the old version.

\section{DISCUSSION}

The better coincidence of the new ICF index results (Solà et al., 2011) with the fish pass effectiveness estimation for the seven fish passes compared to that obtained with the old ICF version (Table 4) is not surprising, as the new version of the ICF was changed mainly to integrate the fish pass effectiveness criteria described in this study (Solà et al., 2011). Although the results of the new ICF index are consistent, they come from a relatively small number of cases (7 until 2009). Therefore, it will be necessary to replicate this study in additional fish passes to validate these results. However, the most reliable way to verify the effectiveness of a fishway is estimation of the rate of fish passage, which is defined as the amount of fish per unit of time that can ascend the barrier through the passage device (Travade \& Larinier, 2002; Marmulla \& Welcomme, 2002; Roni, 2005). We believe that the new ICF version could produce reliable estimates and, thus, could provide an efficient and cost-effective tool to be applied over wide geographical areas.

Regarding the independent results obtained for each of the 7 fish passes evaluated, it is important to note that HPW1 had a clear barrier effect for YOY trout and for young and adult Western Mediterranean barbel. However, this was not sufficient to produce clear differentiation in the upstream and downstream population size structures. Moreover, ongoing migration of only larger barbels (basically females) could cause reproduction and isolation problems for this species and greatly reduce its population abundance in this river (Thorncraft \& Harris, 2000; Lucas \& Baras, 2001). The main constraint in this case seemed to be high water velocity between pools $\left(>2 \mathrm{~m} \mathrm{~s}^{-1}\right)$ and low pool depths $(<0.01 \mathrm{~m})$. Moreover, GS1 was assumed to exert a clear barrier effect for mullets and Ebro barbel and probably for other species present. In this case, the main problem is associated with the existence of traverses $0.25 \mathrm{~m}$ in height and some of $0.6 \mathrm{~m}$, which are passable only by large individuals and, thus, represent an impermeable obstacle. However, this obstacle might be permeable to some glass eel individuals migrating through the bridge base, and freshwater blenny might also be able to cross upstream (Travade \& Larinier, 2002; Marmulla \& Welcomme, 2002). In contrast, the HPW2 traverses are only $0.1 \mathrm{~m}$ high, and the water velocity at this site is generally less than $0.5 \mathrm{~m} \mathrm{~s}^{-1}$. These

Table 4. Fish passage rates for Western Mediterranean barbel (Barbus meridionalis) weighted by population size based on depletion electrofishing surveys at the water intake upstream of the fish pass of the Ginestar de Llémena EA009 gauging station (GS3) and at the Llémena stream in Sant Gregori (Ter River basin; el Gironès area, Catalonia) assessed in 2008/2009 (Ordeix et al., 2009b). Tasas de franqueo del barbo de montaña (Barbus meridionalis), ponderadas con el tamaño poblacional obtenido mediante la realización de pescas eléctricas sucesivas, en la entrada del agua aguas arriba del dispositivo de paso para peces de la estación de aforo EA009 de Ginestar de Llémena (GS3) en el río Llémena en Sant Gregori (cuenca del río Ter; comarca del Gironès, Catalunya) en 2008 y 2009 (Ordeix et al., 2009b).

\begin{tabular}{lccc}
\hline Month & $\begin{array}{c}\text { Indiv. caught } \\
\text { day }^{-1}\end{array}$ & $\begin{array}{c}\text { Percentage of the total indiv. } \\
\text { migrators trapped day }\end{array}$ & $\begin{array}{c}\text { Percentage of the total PIT } \\
\text { tagged indiv. migrators day }\end{array}$ \\
\hline June 2008 & $3.0-2.8$ & $0.2-0.4 \%$ & - \\
\hline April 2009 & 0.1 & $0.01 \%$ & $0.7 \%$ \\
\hline June 2009 & $2.1-1.3$ & $0.2-0.3 \%$ & $0.01 \%$ \\
\hline November 2009 & 0.2 & $0.004 \%$ & 01 \\
\hline
\end{tabular}


conditions are quite appropriate for most of the fish present to cross. However, the fish pass is only $0.75 \mathrm{~m}$ wide, while the weir is $70 \mathrm{~m}$ wide, and the flow through the fish pass (when water flows through the fish pass are $>0.03 \mathrm{~m}^{3} \mathrm{~s}^{-1}$ ) is extremely low in relation to the river flows (0.3-9.0 $\mathrm{m}^{3} \mathrm{~s}^{-1}$ between 07/04/12 and 07/11/07). All of these conditions have been shown to limit fish crossing rates elsewhere (Larinier, 2002a; Larinier, 2002b; Larinier, 2002c; Larinier et al., 1994; Marmulla \& Welcomme, 2002; Armstrong et al., 2004; Kroes et al., 2006).

HPW3 only produced a large barrier effect in low flow conditions, when the low water level (max. $0.2 \mathrm{~m}$ ) in the deflector does not allow brown trout passage upstream and quite likely also prevents the passage of the other two native fish species. In contrast, the fish passage rates at GS2 were low but similar to those observed for small cyprinids at other fish passes in Catalan rivers (HPW2, GS3 and IW1) during the same study period. It is worth noting that glass eels were observed in May climbing a vertical $\left(90^{\circ}\right)$ wall of concrete but failing to reach the top of the barrier because it was covered by a steel beam with overhanging material. This finding represents a major problem for the migration of glass eels and has also been documented in other studies (Larinier, 2002d; Armstrong et al., 2004). Finally, deficiencies in the design of the fish pass at GS3 include insufficient pool depth, excessive height over the first jump (although this was improved in 2009) and a current velocity that is too high for the majority of cyprinid species (often $>2 \mathrm{~m} \mathrm{~s}^{-1}$ ). However, these deficiencies only seem to effect smaller Western Mediterranean barbel individuals. Likewise, IW1 is assumed to represent an obstacle to colonising upstream areas for Ebro barbel, and the first appearance of this species upstream sections might be related to the construction of the new fish pass at the gauging station (July 2008).

In summary, brown trout ( $S$. trutta), which exhibit a high capacity to overcome obstacles by swimming and/or jumping (Larinier et al., 1994; Armstrong et al., 2004), seem to be able to migrate upstream using the different types of fish passes present in Catalonia. However, our results showed that if fish pass waterfalls are higher than $0.2 \mathrm{~m}$ and/or fish pass water velocity is higher than $2 \mathrm{~m} \mathrm{~s}^{-1}$, only the largest individuals of species with a moderate capacity to overcome obstacles, including Mediterranean mullets ( $L$. ramada, M. cephalus and C. labrosus) and some cyprinid species, such as Ebro barbel (L. graellsii; FL $>55 \mathrm{~mm})$, Western Mediterranean barbel $(B$. meridionalis; FL $>0.13 \mathrm{~m}$ ), Iberian redfin barbel (B. haasi) and Ebro chub (S. laietanus), are able to cross upstream. Moreover, if a fish pass waterfall has a maximum height of $0.1 \mathrm{~m}$ and/or a water velocity of less than $0.5 \mathrm{~m} \mathrm{~s}^{-1}$, our results showed that most species and individuals can use the fish pass, including small species with a low capacity to overcome obstacles, such as Pyrenean gudgeon ( $G$. lozanoi), Pyrenean minnow (P. bigerri), European eel (A. anguilla), and YOY of other species including brown trout (S. trutta), Ebro barbel (L. graellsii) and Western Mediterranean barbel (B. meridionalis; $\mathrm{FL}<0.09 \mathrm{~m}$ ). Finally, important movements of fish were mostly associated with particular spawning periods and/or periods just after high or moderate peak flows, as has being indicated in many other studies (Reiser \& Peacock, 1985; Larinier et al., 1994; Lucas \& Baras, 2001; Marmulla \& Welcomme, 2002). This finding also supports the idea that fish pass evaluation should be performed at times of maximum activity of different fish species: early spring for mullet species, spring for cyprinids and autumn for salmonids.

Currently, there are few examples in Catalonia of close-to-nature fish passes and dam or weir removals compared to other areas of the Iberian Peninsula (Brufao, 2006) or the European Union. All solutions regarding fish passages should be established based on criteria related to their effectiveness and with the participation of experts on fish and river connectivity during the design and construction processes. It is important to restore connectivity for at least a thousand obstacles in Catalonia if a good ecological status is to be achieved, and in light of the present results, multispecies fishways are recommended in most locations. A restoration programme should consider the preferred option of dam and weir removal or, where necessary, the construction of close-to-nature devices, such as fish ramps, rock 
ramps, by-pass channels or streams, and in exceptional cases, broad-spectrum technical solutions, such as pool passes with low waterfalls and water velocities (Marmulla \& Welcomme, 2002).

Finally, the mobility of the native fish fauna, including their capacity to use upstream passage devices or negotiate artificial barriers to fish passage and their natural patterns of movement, is still poorly understood (Jungwirth et al., 1998; Marmulla \& Welcomme, 2002; Kroes et al., 2006). Thus, additional research on these issues for all native species is urgently required. Moreover, fish passage projects could provide insight into fish movement patterns. However, these projects often do not have sufficient resources for adequate assessment of fish pass effectiveness, and they provide patchy knowledge regarding fish movement patterns (Lucas \& Baras, 2001; Roni, 2005). Advancing our understanding of fish movement patterns will require regularly monitoring the efficiency of the principle fish migration solutions, especially in large rivers because of their importance for amphidromous, anadromous and catadromous fish species. For fishways situated in key locations, for example, in the lower parts of rivers, it would be appropriate to adapt fish pass structures to enable the installation of large permanent fish traps, as has been performed in many European countries, especially those that have important salmon or eel fisheries (Reddin et al., 1992; Eatherley et al., 2005; Kroes et al., 2006), or automatic fish counting devices (e.g., based on electric resistivity, infrared light and/or an additional video camera system; Dunkley et al., 1992; Thorley et al., 2005; DEFRA, 2010).

\section{CONCLUSIONS}

We highlight the following conclusions:

- The existing solutions in Catalonia to improve fish migration are insufficient, and where they do exist, fish passes are usually inadequate or poorly maintained, or insufficient for all of the native fish fauna from each water body.
- With few exceptions, fish passage rates are too low, and in many cases, fish passes only facilitate the upstream movements of larger fish, often predominantly females of cyprinid species.

- The observed fish pass effectiveness agrees with the results of a quick assessment technique: the new version of the ICF index; the evaluation of longitudinal connectivity using the old version of the ICF index does not correspond to any of the estimates for fish pass effectiveness. In addition, due to the variety of species and hydrological regimes addressed and solutions used to date, it is essential to complement this quick assessment technique with determination of the in situ fish pass effectiveness of any new solution implemented.

\section{ACKNOWLEDGMENTS}

This research is part of an agreement between the Agència Catalana de l'Aigua (Water Catalan Agency) and CERM, Centre d'Estudis dels Rius Mediterranis-Museu industrial del Ter (Center for the Study of Mediterranean Rivers-Industrial Museum of the Ter River) based on the Water Framework Directive and the Environmental Flows Plan for Catalonia (7/2006).

We are grateful for the goodwill, cooperation and trust shown by Gabriel Borràs, Jordi Pagès, Jordi Pastor, Juanjo Villegas, Jorge Helmbrecht, Alfredo Pérez, Àlex Rocas, Rosa Maria Satorra, Salvador Sosa, David Gifreu, Agustí Alberca, Nadal Badia, Carlos Hernández, Josep Maria Torremilans, Francesc Marsà, Carles Setó, Jordi Clusellas, Ramon Martín, Toni Olm, Tomàs Pastor and Meritxell Salvador of the Water Catalan Agency.

Similarly, we are grateful for the interest and support of Miquel Arilla, Josep Maria Puigaranau, Francesc Coll and Jordi Arumí, the Cos d'Agents Rurals de la Generalitat de Catalunya, Joan Carles Sánchez and Montse Tura, the Federació Catalana de Pesca, and Pere Aymerich when he was the biologist in the Natural Park of the High Pyrenees. 
We are also grateful for the facilities offered by the following consulting companies: Joan Girbau, by Girbau Consulting, SL, Sebastià Riba, by Picht \& Put Mas d'Osor, Albert Sorolla, by Naturalea, Francesc Córdoba, by Fractàlia, Jordi Plana and Joan Hurtós, by Plana-Hurtós enginyers, Bernart Delerve, by Golf Camprodon, Claudi Racionero, by ECAFIR, and Jordi Barceló, by OPYCE, SA.

The contributions of Peter Paul Scholema and Herman Wanningen (Hunze en Aa's Waterboard, the Netherlands), Martin Kroes (Visadvies, the Netherlands), Greg Armstrong and Peter Gough (Environment Agency of Wales, United Kingdom), Miguel Clavero, Ramon Moreno and Lluís Zamora (University of Girona), Rafel Rocaspana, Antoni Palau (FECSA-ENDESA) and Frederic Casals (University of Lleida) are also acknowledged.

We are grateful for the support of other colleagues from CERM who, at different times, have participated in this project: Èlia Bretxa, Gregori Conill, Xevi Crosas, Laia Jiménez, Francesc Llach, Jesús Ortiz, Romero Roig and Montse Roura.

We also thank an anonymous reviewer for helping us to improve the manuscript with their comments and corrections.

Finally, to our families, friends and colleagues who helped us to check fish traps in many rivers and streams and, from day to day, became more involved in fish migration issues and in nature conservancy.

\section{REFERENCES}

AGÈNCIA CATALANA DE L'AIGUA (ACA). 2006. HIDRI. Protocolo para la valoración de la calidad hidromorfológica de los ríos. Departament de Medi Ambient i Habitatge, Generalitat de Catalunya. Barcelona, Catalonia. 158 pp. Available in internet: http://aca-web.gencat.cat/aca.

AGÈNCIA CATALANA DE L'AIGUA (ACA). 2009.

Trabajos para la redacción de las "Bases técnicas para el desarrollo del Programa de Medidas enfocado a la mejora de la conectividad fluvial en Catalunya". Departament de Medi Ambient i Habitatge, Generalitat de Catalunya. Barcelona, Catalonia. Unpublished document. 126 pp. Available in internet: http://aca-web.gencat.cat/aca.
AMSTRONG, G. S., M. W. APHRAHAMIAN, G. A. FEWINGS, P. J. GOUGH, N. A. READER \& P. V. VARALLO. 2004. Environment Agency Fish Pass Manual: Guidance Notes on the Legislation, Selection and Approval of Fish Passes in England and Wales. Environment Agency. Wales, United Kingdom. 313 pp.

AMSTRUP, S. C., T. L. McDONALD \& B. F. J. MANLY (eds.). 2005. Handbook of Capture-Recapture Analysis. Princeton University Press. Priceton, New Jersey, United States o f America. 313 pp. APARICIO, E., M. J. VARGAS, J. M. OLMO \& A. SOSTOA. 2000. Decline of native freshwater fishes in a Mediterranean watershed on the Iberian Peninsula. Environmental Biology of Fishes, 59(1): 11-19.

BRUFAO, P. 2006. La demolición de presas en España: un repaso por Comunidades Autónomas. Quercus, 241: 34-41.

BRUSLÉ, J. \& J. P. QUIGNARD. 2001. Biologie des poissons d'eau douce européens. Editions Tec\& Doc. Paris, France. 625 pp.

CASALS, F. 2005. Les comunitats íctiques dels rius mediterranis: relacions amb les condicions ambientals. Thesis, Barcelona University. Barcelona, Catalonia. 353 pp.

CATALAN, J., R. VILALTA, B. WEITZMANN, C. PIGEM, M. VENTURA, R. ARANDA \& E. COMAS. 1997. L'obra hidraúlica als Pirineus. Avaluació, correcció i prevenció de l'impacte mediambiental. ENHER, Fundació La Caixa \& FECSA. Barcelona, Catalonia. 890 pp.

COWX, I. G. \& R. L.WELCOMME (eds). 1998. Rehabilitation of rivers for fish. Food and Agriculture Organization of the United Nations (FAO) by Fishing News Books (Blackwell Science Ltd). Oxford and Northampton, United Kingdom. 260 pp.

CLAVERO, M., F. BLANCO-GARRIDO \& J. PRENDA. 2006. Monitoring small fish populations in streams: a comparision of four passive methods. Fisheries research, 78: 243-251.

DEPARTMENT FOR ENVIRONMENT, FOOD AND RURAL AFFAIRS (DEFRA). 2010. Eel Management plans for the United Kingdom North West River Basin District. UK Government London, UK. 27 pp. Available in internet: http://ww2.defra. gov.uk/

DOADRIO, I. (Ed.). 2001. Atlas y libro rojo de los peces continentales de España. Consejo Superior de Investigaciones Científicas. Ministerio de Medio Ambiente. Madrid, Spain. 364 pp. 
DUNKLEY, D. A. \& W. M. SHEARER. 1982. An assessment of the performance of a resistivity fish counter. Journal of Fish Biology, 20: 717-737.

EARTHERLEY, D. M. R., J. L. THORLEY, A. B. STEPHEN, I. SIMPSON, J. C. MACLEAN \& A. F. YOUNGSON. 2005. Trends in Atlantic salmon: the role of automatic fish counter data in their recording. Scottish Natural Heritage Commissioned Report No. 100 (ROAME No. F01NB02). UK.

EC. 1992. Council Directive 92/43/EEC of 21 May 1992 on the conservation of natural habitats and of wild fauna and flora.

EC. 2000. Directive 2000/60/EC of the European Parliament and of the Council of 23 October 2000 establishing a framework for Community action in the field of water policy. Official Journal of the European Communities.

EC. 2007. Council Regulation (EC) No 1100/2007 of 18 September 2007 establishing measures for the recovery of the stock of European eel.

ELVIRA, B., G. G. NICOLA \& A. ALMODÓVAR. 1998a. Impacto de las obras hidráulicas en la ictiofauna. Dispositivos de paso para peces en las presas de España. Colección técnica. Organismo Autónomo de Parques Naturales. Ministerio de Medio Ambiente. Madrid, Spain. 208 pp.

ELVIRA, B., G. G. NICOLA \& A. ALMODÓVAR. 1998b. Sistemas de paso para peces en presas. Centro de Estudios y Experimentación de Obras Públicas. Madrid, Spain.

ENCINA, L., A. RODRÍGUEZ, C. GRANADO \& C. ESCOT. 2001. Gestión y evaluación de embalses: estudio de las poblaciones de peces. Universidad de Sevilla. Consergería de obras públicas y transportes. Sevilla, Spain.

GARCÍA, J., A. LLANOS \& A. MARTÍNEZ DE AZAGRA. 2005. Diseño de obras de paso compatibles con la migración de peces. Design of fishfriendly culvert crossings. Ingeniería Civil, 139(1): 132-139.

GRANADO, C. 2000. Ecología de comunidades: El paradigma de los peces de agua dulce. Sevilla University. Sevilla, Spain.

JONSSON, N. 1991. Influence of water flow, water temperature and light on fish migration in rivers. Nordic Journal of Freshwater Research, 66: 20-35.

JUNGWIRTH, M., S. SCHMUTZ \& S. WEISS (eds). 1998. Fish migration and Fish Bypasses. Fishing News Books, Blackwell Science Ltd. Cambridge, United Kingdom. 438 pp.
KROES, M. J., P. GOUGH, H. WANNINGEN, P. P. SCHOLLEMA, M. ORDEIX \& D. VESELÝ. 2006. From sea to source. Practical guidance for the restoration of fish migration in European Rivers. Interreg IIIC Project "Community Rivers". Hunze en Aa's Water Board. Gröningen, The Netherlands. 119 pp.

LARINIER, M. 2001. Environmental issues, dams and fish migration. In: Dams, fish and fisheries. Opportunities, challenges and conflict resolution. G. Marmulla (ed.): 45-89. Food and Agriculture Organization of the United Nations (FAO), Rome, Italy.

LARINIER, M. 2002a. Location of fishways. Bull. Fr. Pêche Piscic., 346 suppl.: 39-53.

LARINIER, M. 2002b. Pool fishways, pre-barrages and natural bypass channels. Bull. Fr. Pêche Piscic., 346 suppl.: 54-82.

LARINIER, M. 2002c. Fish passages through culverts, rock weirs and estuarine obstructions. Bull. Fr. Pêche Piscic., 346 suppl.: 119-134.

LARINIER, M. 2002d. Biological factors to be taken into account in the design of fishways, the concept of obstructions to upstream migration. Bull. Fr. Pêche Piscic., 346 suppl.: 28-38.

LARINIER, M., J. P. PORCHER, F. TRAVADE \& C. GOSSET. 1994. Passes à poissons. Expertise et conception des ouvrages de franchissement. Collection Mise au point. Conseil Supérieur de la Pêche. Paris, France. 336 pp.

LOBÓN-CERVIÁ, J. 1991. Estudio de poblaciones de peces en ríos. Pesca eléctrica y métodos de estima de la abundancia. Museo Nacional de Ciencias Naturales-Consejo Superior de Investigaciones Científicas. Madrid. 156 pp.

LUCAS, M. C. \& E. BARAS. 2001. Migration of Freshwater Fishes. Blackwell Science. Oxford, United Kingdom. 420 pp.

MARMULLA, G. \& R. L. WELCOMME (eds.). 2002. Fish passes. Design, dimensions and monitoring. Food and Agriculture Organization of the United Nations (FAO) \& Deutscher Verband für Wasserwirtschaft und Kulturvau (DVWK). Roma, Italy. 118 pp.

ORDEIX, M., Q. POU-ROVIRA, N. SELLARÈS, A. MUNNÉ, J. PAGÈS \& C. SOLÀ. 2006. Avaluació dels dispositius de pas per a peixos per a l'anàlisi de la connectivitat als rius de Catalunya. Agència Catalana de l'Aigua, Departament de Medi Ambient i Habitatge, Generalitat de Catalunya. Barcelona, Catalonia. Unpublished docu- 
ment. 289 pp. Available in internet: http://aca-web. gencat.cat/aca.

ORDEIX, M., J. VAN HERK, H. WANNINGEN, C. PINTOR \& C. DURÁN. 2009a. Asistencia técnica para el estudio de propuestas de mejora de la conectividad para los peces en la parte baja del río Ebro. CERM, Centre d'Estudis dels Rius MediterranisMuseu Industrial del Ter, LINKit Consult \& Wanningen Water Consult. Done for the Confederación Hidrográfica del Ebro. Zaragoza, Spain. 48 pp. Available in internet: http://oph.chebro.es/DOCUMENTACION/Calidad/CalidadDeAguas.html. ORDEIX, M., Q. POU-ROVIRA, N. SELLARÈS, A. MUNNÉ, M. BARDINA, C. SOLÀ \& J. PAGÈS. 2009b. Avaluació de l'eficàcia de sis dispositius de pas per a peixos dels rius de Catalunya. Anys 2006-2009. Treballs preliminars a la redacció del Pla de Millora de la Connectivitat fluvial a Catalunya. Agència Catalana de l'Aigua, Departament de Medi Ambient i Habitatge, Generalitat de Catalunya. Barcelona, Catalonia. Unpublished document. 189 pp. Available in internet: http://acaweb.gencat.cat/aca.

PORCHER, J. P. \& F. TRAVADE. 2002. Fishways: biological basis, limits and legal considerations. Bull. Fr. Pêche Piscic., 346 suppl.: 9-20.

REDDIN, D. G., M. F. O'CONNELL \& D. A. DUNKLEY. 1992. Assessment of an automated fish counter in a Canadian river. Aquaculture Research, 23: 113-121.

REISER, D. W. \& R. T. PEACOCK. 1985. A technique for assessing upstream fish passage problems at small-scale hydropower developments. In: Symposium on small hydropower and fisheries. American Fisheries Society, Western Division, Bethesda, Maryland: 423-432.

RODRÍGUEZ-RUIZ, A. \& C. GRANADO-LORENCIO. 2006. Spawning period and migration of three species of cyprinids in a stream with Mediterranean regimen (SW Spain). Journal of Fish Biology, 41(4): 545-556.

RONI, P. (ed.) 2005. Monitoring Stream and Watershed Restoration. American Fisheries Society. Bethesda, Maryland, EUA. 350 pp.

SANTO, M. 2005. Dispositivos de passagem para peixes em Portugal. Direcçao-Geral dos Recursos Florestais. Editideias-Ediçao e Produçao, Lda. Lisboa, Portugal. 137 pp.
SANTOS, J. M., M. T. FERREIRA, A. N. PINHEIRO \& J. BOCHECHAS. 2006. Effects of small hydripower plants on fish assemblages in mediumsized streams in central and northern Portugal. Aquatic Conservation: Marine and Freshwater Ecosystems, 16: 373-388.

SOLÀ, C., M. ORDEIX, Q. POU-ROVIRA, N. SELLARÈS, A. QUERALT, M. BARDINA, A. CASAMITJANA \& A. MUNNÉ. 2011. Longitudinal connectivity in hydromorphological quality assessments of rivers. The ICF index: A river connectivity index and its application to Catalan rivers. Limnetica, 30(2): 273-292.

SOSTOA, A. 1990. Peixos. Història Natural dels Països Catalans, 12. Enciclopèdia Catalana, SA. Barcelona, Catalonia. 487 pp.

SOSTOA, A., N. M. CAIOLA, D. VINYOLES, S. SÁNCHEZ, C. FRANCH, F. CASALS, L. GODÉ \& A. MUNNÉ. 2003. Desenvolupament d'un index d'integritat biòtica (IBICAT) basat en l'ús dels peixos com a indicadors de la qualitat ambiental dels rius de Catalunya. Aplicació de la Directiva Marc en Política d'Aigües de la Unió Europea (2000/60/CE). Agència Catalana de l'Aigua, Departament de Medi Ambient, Generalitat de Catalunya. Barcelona, Catalonia. 204 pp. Available in internet: http://aca-web.gencat.cat/aca.

TRAVADE, F. \& M. LARINIER. 2002. Monitoring techniques for fishways. Bull. Fr. Pêche Piscic., 346 suppl.: $166-180$.

THORLEY, J. L., D. M. R. EATHERLEY, A. B. STEPHEN, I. SIMPSON, J. C. MACLEAN \& A. F. YOUNGSON. 2005. Congruence between automatic fish counter data and rod catches of Atlantic salmon (Salmo salar). Scottish Rivers Journal of Marine Science, 62: 809-817.

THORNCRAFT, G. \& J. H. HARRIS. 2000. Fish Passage and Fishways in New South Wales: a Status Report. Centre for Fresh Water Ecology, Australia. $32 \mathrm{pp}$.

WELCOMME, R. L. 1980. Cuencas fluviales. Food and Agriculture Organization of the United Nations (FAO). Rome, Italy. 62 pp.

ZITEK, A., S. SCHMUTH \& M. JUNGWIRTH. 2008. Assessing the efficiency of connectivity measures with regard to the EU-Water Framework Directive in a Danube-tributary system. Hydrobiologia, 609: 139-161. 